\title{
Comparative effect of Rhizophagus irregularis strain on cassava root development and Phosphorus uptake under acidic soils conditions of Walungu territory, Eastern DR Congo.
}

Adrien Byamungu Ndeko*, Geant Chuma Basimine, Espoir Mukengere Bagula, Yannick Mugumaarhahama, Bintu Nabintu Ndusha, Pierrette Rehema, Gustave Mushagalusa Nachigera. Université Evangélique en Afrique, Faculty of Agricultural Sciences and Environment, Department of Plant production, Laboratory of molecular biology and biotechnology, P.O.Box 3323 Bukavu, Democratic Republic of Congo. Corresponding author: ndeko.byam@gmail.com \& ndekobyamungu@uea.ac.cd

Original submitted in on $5^{\text {th }}$ December 2019. Published online at www.m.elewa.org/journals/ on $30^{\text {th }}$ April 2020 https://doi.org/10.35759/JABs.148.1

\begin{abstract}
Objective: In the highlands of South-Kivu province of DRCongo, cassava is grown on marginal land not suitable for other crops. Walungu territory for instance is dominated by acidic soils and has the highest nutrient depletion rate in the country. On such types of soil, nutrient depletion is accompanied by a decrease in the availability of phosphorus and many other nutrients. The use of Arbuscular mycorrhizal fungi (AMF) would therefore be an alternative to improve the phosphate nutrition of cassava under different soil conditions. Methodology and results: The experiment reported in the current study was conducted in pots under semicontrolled conditions. Ferrallitic soil from Walungu was used. Soil was sterilized or not and then inoculated with the AMF Rhizophagus irregularis (RI) strain. Results showed that inoculation with an exotic AMF strain (Rhizophagus iregularis) has significantly increased root abundance (number of roots) in both sterilized and unsterilized soil and root dry weight in sterilized soil only. However, in unsterilized soil, root dry weight decreased with AMF inoculation. In Walungu acidic soils, P supply could significantly influence the effect of mycorrhizal inoculation on root development and root abundance. AMF inoculation has significantly increased the shoot $P$ concentration when $P$ was supplied. In sterilized soil, mycorrhizal inoculation had a depressant effect on soil phosphorus concentration, especially when $P$ was not supplied.

Conclusion and application of results: Our results suggest that the introduced Rhizophagus iregularis strain increases $P$ uptake in the rhizospheric soil, especially when phosphorus is not applied to the sterilized or unsterilized soil. The use of the Rhizophagus irregularis strain as a biofertilizer could improve phosphorus nutrition and root development in cassava.
\end{abstract}

Keywords: Arbuscular mycorrhizae, Rhizophagus irregularis, P uptake, Cassava, Ferrallitic soil

\section{INTRODUCTION}

Low soil fertility is known to be the factor limiting the productivity of agricultural systems in sub-Saharan Africa (Agbaje and Akinlosotu, 2004). This is attributed to high population density and high dependence on agriculture in most rural areas of Africa. In addition, there is a high level of degradation of agricultural land resulting in low water retention capacity and essential nutrients 
including nitrogen, phosphorus and potassium (Cassman et al, 2002; Kintché et al., 2017). In the highlands of South-Kivu province, Cassava monocropping system is only done on marginal lands, unsuitable for other crops (Cox, 2008; Pypers et al., 2011). Under this category fall, Walungu soils which have been described as very acidic $(\mathrm{pH}$ between 3.96 and 5.54), with high levels of iron and aluminium oxides that limit bioavailability and significantly reduce the rate of orthophosphate ions in the soil solution (Bagula et al , 2014). Under these conditions, phosphorus deficiency due to the presence of $\mathrm{Fe}$ and $\mathrm{Al}$ constitutes one of the factor limiting cassava yield under field conditions (Pellet and E-sharkawy, 1993). Phosphorus is of crucial importance, needed for plant development and growth. In tropical regions, however, lack of phosphate nutrition is still one of the main constraints limiting plant development and crop yield in degraded soils (Hinsinger et al., 2015). Experiments have shown for example that phosphorus inputs of about 100 to $150 \mathrm{~kg} \mathrm{ha}^{-1}$ can improve cassava yield. Nevertheless, the high cost of phosphate fertilizers still limits their use by smallholder farmers, who are often poor and resource-constrained. In order to overcome these problems, the use of alternative sources of phosphorus is essential. The exploitation of mycorrhizal symbiosis stands as one of the sources

\section{MATERIALS AND METHODS}

Plant material, growth conditions and planting: The experiment was conducted in the greenhouse of the Faculty of Agricultural Sciences and environment of the Université Evangélique en Afrique (DRC, $2^{\circ} 54387 \mathrm{~S}$ Lat, $28^{\circ} 86059 \mathrm{E}$ Long, $1675 \mathrm{~m}$. Alt) where the average temperature is $20^{\circ} \mathrm{C}$ during the day and $16^{\circ} \mathrm{C}$ at night (Yali, 2004). Planting was done in plastic pots with a capacity of $4 \mathrm{~kg}$ of soil $(25 \times 9,5 \mathrm{~cm})$. The Sawasawa variety of cassava, developed by IITA (International Institute of Tropical Agriculture) Kalambo, was used in this experiment. This variety is well known for her resistance to African cassava mosaic virus (ACMV). Pots used for experiment were arranged in a split plot design with three factors $(2 \times 2 \times 2 \times 4)$ consisting of two levels of mycorrhizal inoculation (with and without AMF inoculation), two soil conditions (sterilized soil vs that could yield interesting results (Aime et al., 2016; Kintché et al., 2017; Munyahali et al., 2017). Arbuscular Mycorrhizal Symbiosis plays an important role in plant growth and mineral nutrition. Some species in particular have the ability to mobilize and solubilize organic phosphorus from the soil by making it available to plants as phosphate ions (Okon, 2010). Studies have shown that extramatricial hyphae of AMF could improve absorption, transfer and assimilation of nitrogen and phosphorus for the host plants. Its beneficial effect mainly depends on the genotypes and growth stage of host plants and inoculated AMF strains (Okon, 2010; Taylor et al., 2014; Turrini et al., 2017). However, it has been recognized that the dependency of some root crops like cassava on mycorrhizal is high, especially for nutrient uptake from the soil (Cavender et al., 2003; Carretero et al., 2009), its response to mycorrhizal inoculation in highly acidic soil has not yet been thoroughly investigated. Moreover, as suggested by empirical evidence, inoculation with high efficient strains could increase the nutrient absorption efficiency of cassava plants. Therefore, the objective of this study was to investigate the effects of mycorrhizal inoculation on root development and P uptake in cassava plants under different soil conditions with or without phosphorus application.

unsterilized soil) and two levels of phosphorus supply (with phosphorus supply vs without phosphorus supply). With 32 pots, each treatment was repeated four times. Pots were randomly arranged each week to avoid the effect of positioning. Soil samples were collected from Walungu territory in farmer fields in Burhale Sub-County (Lat, $2.692^{\circ} \mathrm{S}$, Long, $28.647^{\circ} \mathrm{E}$, Lat; $1700 \mathrm{~m}$ above sea level) and were used as a growing medium. This is a Ferralsols commonly known as Kalongo (red soil), according to the soil map of Belgian Congo and RuandaUrundi, Dorsale de Kivu, following the classification system of Institut National pour l'Etude Agronomique du Congo Belge (INEAC). This soil is characterized by a high aluminium saturation rate, a very low $\mathrm{pH}$, a low cation exchange capacity, a low organic manure rate and a low level of available phosphorus (Deckers et al. 2003). The soil characteristics are listed in the table below; 
Table 1: Soil characteristics of the top soil $(0-20 \mathrm{~cm})$ in Burhale, DR Congo.

\begin{tabular}{|c|c|c|c|}
\hline Property & Units & Mean & Range \\
\hline $\mathrm{pH}\left(\mathrm{H}_{2} \mathrm{O}\right)$ & & 5.31 & $4.62-5.86$ \\
\hline Organic C & $(\%)$ & 2.48 & $1.23-4.24$ \\
\hline Total N & (\%) & 0.22 & $0.10-0.41$ \\
\hline Olsen-P & $\left(\mathrm{mgRg}^{-1}\right)$ & 8.20 & $3.59-21.7$ \\
\hline Exchangeable K & $\left(\mathrm{cmol}_{\mathrm{c}} \mathrm{kg}^{-1}\right)$ & 0.91 & $0.24-2.47$ \\
\hline Exchangeable Mg & $\left(\mathrm{cmol}_{\mathrm{Cg}} \mathrm{kg}^{-1}\right)$ & 1.22 & $0.15-1.90$ \\
\hline Exchangeable $\mathrm{Ca}$ & $\left(\mathrm{cmol}_{\mathrm{Cg}} \mathrm{kg}^{-1}\right)$ & 3.80 & $0.97-6.50$ \\
\hline Exchangeable acidity & $\left(\mathrm{cmol}_{\mathrm{C}} \mathrm{kg}^{-1}\right)$ & 0.68 & $0.00-2.46$ \\
\hline ECEC & $\left(\mathrm{cmol}_{\mathrm{c}} \mathrm{kg}^{-1}\right)$ & 6.60 & $3.06-9.85$ \\
\hline Clay & $(\%)$ & 32 & $17-58$ \\
\hline Silt & $(\%)$ & 17 & $14-24$ \\
\hline Sand & $(\%)$ & 51 & $28-64$ \\
\hline
\end{tabular}

AMF Inoculation and phosphorus application in Pot: To assess the effects of AMF inoculation under different levels of phosphorus supply and soil conditions on root development and $\mathrm{P}$ uptake, one non-indigenous strain Rhisophagus iregularis of arbuscalar mycorrhizal fungi was used. This strain was imported from Kenya as a commercial strain packaged in peat as a conservation substrate. Ten grams $(10 \mathrm{~g})$ of AMF inoculum was applied per pot and placed under cassava cuttings to ensure contact between the plant and the treatment at the root development stage. A cassava cutting was placed at the centre of the pot after the application of TSP and AMF. AMF inoculation treatments were applied to main plot and Phosphorus levels were applied to subplots. Each of the plots was grown under both soil conditions; unsterilized and sterilized soil. The soil was sterilized using an autoclave at $120^{\circ} \mathrm{C}$ for 2 minutes with three repetitions. Phosphorus fertilizer (triple superphosphate) was applied by hand at a rate of 0.43 grams per pot and incorporated into the soil. To avoid any nutritional deficiency during our experiment, nitrogen was supplied in the form of Urea to all plots at a dose of $150 \mathrm{mgN} \mathrm{kg}^{-1}$ of soil, resulting in 1.3 grams of $\mathrm{CO}(\mathrm{NH} 2)_{2}$ per pot. Whereas, $\mathrm{KCl}$ was used at a dose of $150 \mathrm{mg} \mathrm{K}$ $\mathrm{kg}^{-1}$ soil, which corresponds to $1 \mathrm{gram} \mathrm{KCl}$ per pot. Watering was carried out every day depending on the water status of the soil.

\section{RESULTS}

Roots development of cassava plants as affected by AMF inoculation, Soil condition and phosphorus supply: The ANOVA analysis (see table 2?) showed that root length were not significantly influenced by neither $P$ supply, soil conditions nor AMF inoculation. In sterilized
Plant performances and cassava $P$ uptake in pots conditions: Four months after planting, cassava plants were harvested and growth parameters were evaluated. Plants were then separated into roots and shoot after thoroughly washing in water. The measured parameters were root length, root distribution (number of roots) and root biomass. The root length was determined using a graduated ruler of about $30 \mathrm{~cm}$. The number of roots per plant determined by root count evaluated the root distribution. As regard to the root biomass, it was determined by drying the root samples in an oven at $65^{\circ} \mathrm{C}$ for 3 days. The dry weight of the roots determines the root biomass. To assess $P$ uptake among the treatments, Phosphorus concentrations in plant parts were analysed colorimetrically by the molybdate-blue method according to (Murphy and Riley 1962). In addition, the available phosphorus was measured in the soil of each treatment at the end of the experiment. In addition, assimilable phosphorus was measured in the soil of each treatment at the end of the experiment. This was important to assess the influence of mycorrhizal inoculation and other treatments on phosphorus uptake. Statistical Analysis: All data were statistically analysed by XL-Stat version 206. Differences amongst treatments in response to AMF inoculation, $\mathrm{P}$ application and soil conditions were analysed using One-way and three-way of ANOVA. Means were compared with the StudentNewman-Keuls range test $(P<0.05)$.

soil, inoculant of AMF did not increase root length of plants. However, in unsterilized soil root length was increased by AMF inoculation without phosphorus supply. In general, root length was high in absence of mycorrhizal fungi inoculant. It was therefore observed 
that root length tends to decrease with application of mycorrhizal inoculum.

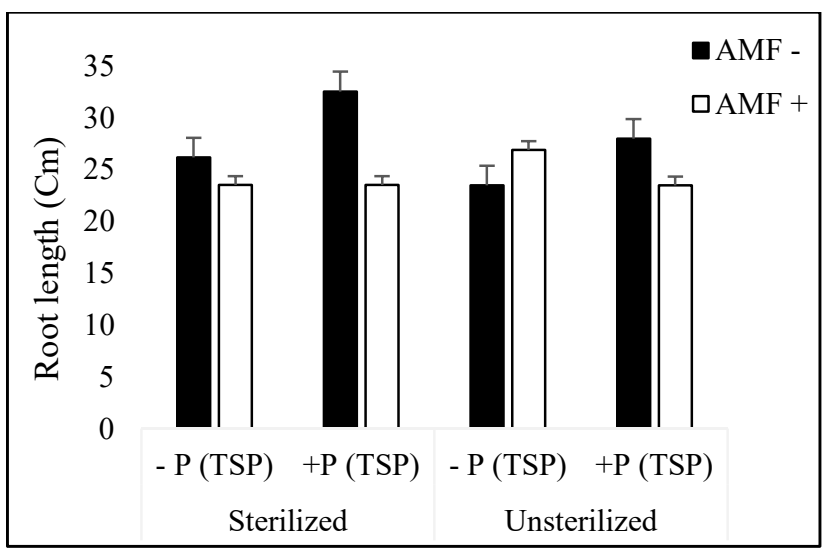

Figure 1: Effect of treatments on the root length of cassava plants

The abundance of root system was evaluated with the number of root per plant, which determines the root distribution. Results showed that the number of root (root distribution) were significantly influenced by the $P$ supply $(p$-value $=<0.0001)$ and AMF inoculation ( $p$-value $=0$. 01). Root distribution was better with $P$ supply compared with treatments without $P$ supply. Under $P$, supply root distribution was better with AMF inoculation in both sterilized and unsterilized soil. However, without $P$ supply, AMF inoculation did not significantly affect root distribution. There was a statistically significant interaction between AMF, P supply $(p<0.0001)$ and soil conditions $(p=0.010)$.

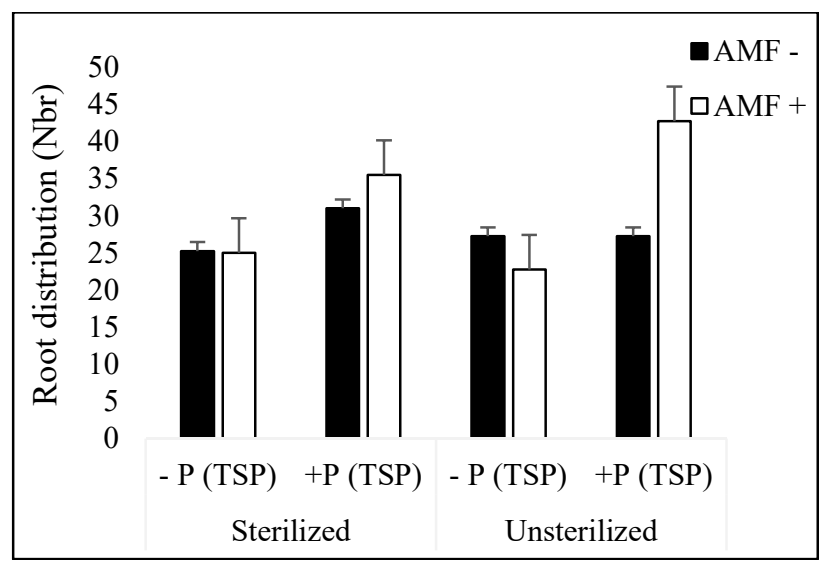

Figure 2: Number of roots formed according to the different treatments

Root dry weight was mainly influenced by the three factors. The highest difference between averages was observed under different soil conditions. Root dry weight significantly increased by $P$ supply independently of AMF inoculation in both sterilized and unsterilized soil. However, in sterilized soil, mycorrhizal plants have a higher root dry weight than the non-mycorrhizal plants under low level of phosphorus. On the other hand, in unsterilized soil, root dry weight has significantly decreased with the AMF inoculation. There was a statistically significant interaction between AMF, soil condition (< 0.0001) and P supply (<0.0001) for the root dry weight. These interactions indicate that in general, unsterilized soil and $P$ supply reduce the effect of AMF inoculation on the root dry weight. 


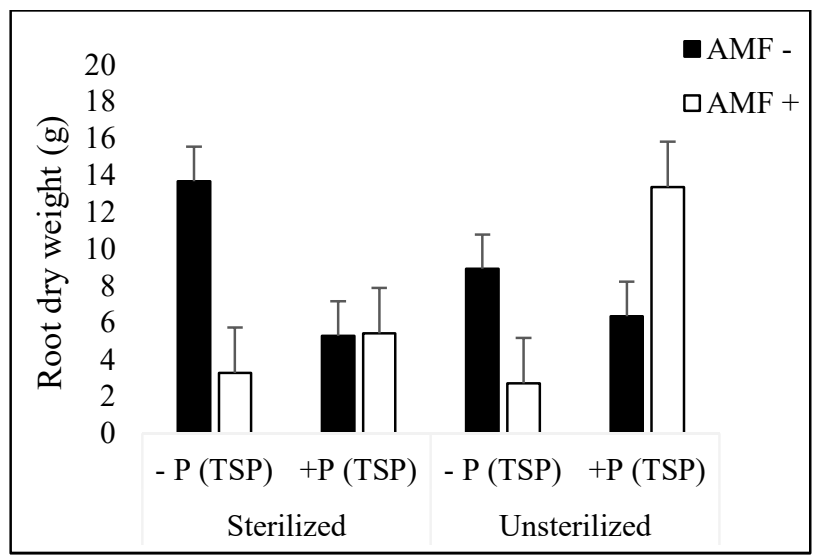

Figure 3: Root dry weight according to the different treatments

Effect of AMF inoculation, $P$ supply and soil condition on plant $\mathbf{P}$ uptake: The level of available phosphorus in shoot was significantly affected by AMF inoculation $(p=0.007)$, P supply $(p=<0.0001)$ and soil condition $(p=<0.0001)$. In sterilized soil, $P$ uptake decrease significantly with AMF inoculation independently of $P$ supply. In unsterilized soil, $P$ uptake was higher in mycorrhizal plants than in non-mycorrhizal plants under $\mathrm{P}$ supply only. There was a significant interaction between AMF, P supply $(p=0.002)$ and soil conditions $(p=<0.0001)$.

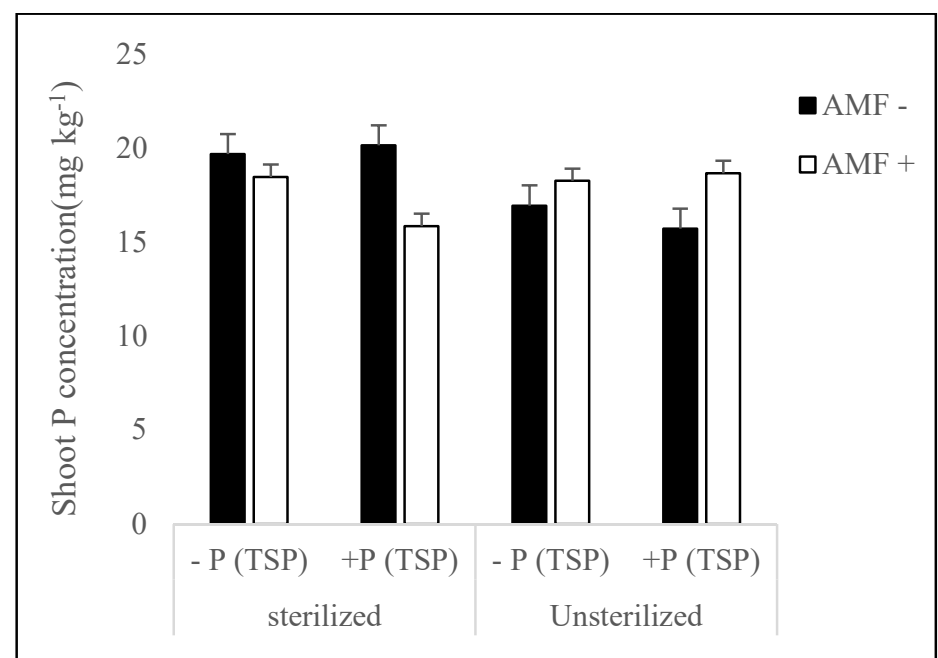

Figure 4: Mean shoot $P$ concentration of AMF inoculated and uninoculated plants under $P$

Soil phosphorus concentration was measured after experiment to assess the amount of phosphorus accumulated because of the various treatments. The ANOVA analysis showed that $P$ concentration in the soil was significantly affected by all the treatments. In unsterilized soil, $P$ concentration was influenced by $P$ supply and AMF inoculation. The soil $P$ concentration level was higher with $P$ input than in soil without $P$ input. The increase in soil $P$ concentration may also be due to the action of mycorrhization following phosphorus solubilization. The strain used (Rhizophagus irregularis) is reported to have a high capacity for soil phosphorus solubilization (Lourdes et al, 2017). In addition, the effect of mycorrhizal inoculation on soil phosphorus concentration was higher in soil with $\mathrm{P}$ input than in soil without $P$ input. However, in sterilized soil, mycorrhizal inoculation had a depressant effect on soil phosphorus concentration, especially without phosphorus input. The results suggest that the Rhizophagus iregularis strain interacts with other microorganisms from the soil to increase phosphorus uptake in the rhizospheric soil, especially when phosphorus is not applied on sterilized or unsterilized soil. There was a significant interaction between AMF inoculation, soil condition $(p=<0.0001)$ and $\mathrm{P}$ supply $(p=<0.0001)$. 


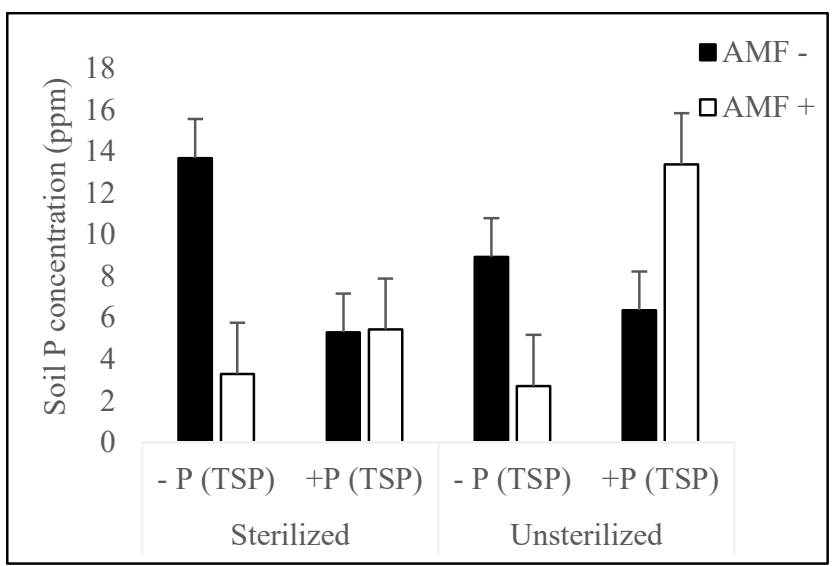

Figure 5: Mean shoot $P$ concentration in with AMF inoculated and uninoculated soil under $P$ supply or no

Table 2: Synthesis of the three-way ANOVA analysis for all variables in the study. Means were compared with the Student-Newman-Keuls range test $(P<0.05)$.

\begin{tabular}{lccccc}
\hline Source of variation & Root length. & Root distribution & Root dry weight & Root_P. Concentration & P.ass. Sol \\
\hline $\mathrm{R}^{2}$ & 0,284 & 0,776 & 0,941 & 0,973 & 0,995 \\
$\mathrm{~F}$ & 1,357 & 11,897 & 55,131 & 122,357 & 745,297 \\
$\mathrm{Pr}>\mathrm{F}$ & 0,268 & $<0,0001$ & $<0,0001$ & $<0,0001$ & $<0,0001$ \\
\hline \multirow{2}{*}{ Sol } & 0,252 & 0,357 & 19,844 & 116,728 & 69,843 \\
& 0,620 & 0,556 & 0,000 & $<0,0001$ & $<0,0001$ \\
\hline \multirow{2}{*}{ TSP } & 0,918 & 44,450 & 113,958 & 49,272 & 17,461 \\
& 0,348 & $<0,0001$ & $<0,0001$ & $<0,0001$ & 0,000 \\
\hline \multirow{2}{*}{ AMF } & 2,634 & 7,867 & 60,098 & 8,778 & 463,077 \\
& 0,118 & 0,010 & $<0,0001$ & 0,007 & $<0,0001$ \\
\hline \multirow{2}{*}{ Sol ${ }^{*}$ TSP } & 0,456 & 0,476 & 0,189 & 9,860 & 1068,553 \\
& 0,506 & 0,497 & 0,667 & 0,004 & $<0,0001$ \\
\hline \multirow{2}{*}{ Sol ${ }^{*}$ AMF } & 1,836 & 1,541 & 131,075 & 535,451 & 634,308 \\
& 0,188 & 0,226 & $<0,0001$ & $<0,0001$ & $<0,0001$ \\
\hline \multirow{2}{*}{ TSP*AMF } & 3,364 & 20,721 & 60,633 & 11,886 & 2926,172 \\
& 0,079 & $<0,0001$ & $<0,0001$ & 0,002 & $<0,0001$ \\
\hline \multirow{2}{*}{ Sol ${ }^{*}$ TSP*AMF } & 0,040 & 7,867 & 0,117 & 124,521 & 37,662 \\
& 0,842 & 0,010 & 0,735 & $<0,0001$ & $<0,0001$ \\
\hline
\end{tabular}

\section{DISCUSSION}

Root development: This work shows that inoculation with an exotic arbuscular mycorrhizal fungi strain has significantly affected the abundance of root system of cassava plants. This study revealed that number of roots was also influenced significantly by the P supply. Under $P$ supply, root distribution was better with AMF inoculation in both sterilized and unsterilized soil. Mohammad, Malkawi and Shibli (2003) reported the same results when they investigated the effect of mycorrhizal inoculation and $P$ fertilization on Barley plant growth. Improved plant growth under different soil conditions could be linked to improved phosphorus uptake due to mycorrhizal symbiosis. The root dry weight was mainly influenced by all the three factors. In sterilized soil, mycorrhizal plants have a high root dry weight than the non-mycorrhizal plants under soil without phosphorus supply. However, in unsterilized soil without P supply, root dry weight have significantly decreased with AMF inoculation indicating the competition between Rhizophagus irregularis and indigenous AMF strains to increase plant $P$ uptake and water nutrition (Biró et al., 2000; Gryndler, 2000; Ortas, Zeina and Sari, 2010). However, under $P$ supply, root dry weight increases with AMF inoculation. Several studies show that AMF are 
actively involved in plant growth through improving water and mineral nutrition. AMFs absorb water and soil nutrients, mainly phosphorus and others such as nitrogen, zinc and potassium, and then pass them to their host plants. This effect also leads to an increase in plant height and biomass (Dalpé, 2005; Jansa, Mozafar and Frossard, 2005; Guissou, 2009). Higher biomass production in mycorrhizal plants compared to nonmycorrhizal plants has been frequently reported and has mainly been attributed to the AMF contribution to $P$ nutrition of the host plant when plants were grown on low P substrates (Sensoy et al., 2007; Dave and Tarafdar, 2011). The increase in root dry mass due to AMF inoculation confirmed the increase in endophyte dependence in the inoculated plants (Ndoye et al., 2016). In addition, both a reduction and an increase in root growth upon mycorrhizal colonization could be observed under favourable conditions. We did not observe any significant response of cassava root length to AMF inoculation even under $P$ supply or not. The decrease of root length of mycorrhizal plants than nonmycorrhizal plants with added insoluble phosphorus was also observed in maize under low soluble ferrous phosphate fertilization (Rakshit and Bhadoria, 2010). This indicates the great development of AMF hyphae.

$P$ uptake: $A$ comparison of $P$ concentration in shoots according to the different treatments showed the contribution of AMF to $P$ nutrition of host plants. In unsterilized soil, $P$ uptake (shoot $P$ concentration) was higher in mycorrhizal plants than in non-mycorrhizal plants with or without $P$ supply. However, in sterilized soil, $P$ uptake decrease significantly with AMF inoculation regardless of $P$ supply indicating that unsterilized soil probably contains more propagules that can induce mycorrhizal symbiosis and phosphorus absorption in cassava plants (Neumann and George, 2004; Ndoye et al., 2013). This result generally supports previous studies (Sawers et al., 2017) according to the evaluation of AMF inoculation, root hyphae development and $\mathrm{P}$ uptake. There was a greatest correlation between

\section{CONCLUSION}

The results indicate that cassava variety used in this study showed a positive response to AMF inoculation according to phosphorus supply and soil conditions. Inoculation with an exotic arbuscular mycorrhizal fungi strain (Rhizophagus iregularis) has significantly increased root abundance (number of roots) in both sterilized and unsterilized soil and the root dry weight in sterilized soil only. However, in unsterilized soil, root dry weight decreased with AMF inoculation. In Walungu the AMF inoculation, root-external hyphae and shoot $P$ concentration. In addition, $P$ concentration increased significantly in the colonized plant materials compared to the non-mycorrhizal plants. AMF help to increase nutrient uptake by increasing the surface area of the plant absorptive system (roots) under P-depletion soil (Azcón-Aguilar and José, 1997). It is known that an AMF association is required for $P$ uptake and plant growth in nearly all soils. In this condition, an increase of $P$ into the labile pool by fertilization would be expected to increase the $P$ uptake ability of the mycorrhizal root system of cassava (Sieverding and Howeler, 1985; Rakshit and Bhadoria, 2010). In addition, under mineral fertilization, mycorrhization can even increase the efficiency of minerals fertilizers to the benefit of plants (Sow et al., 2016). Soil phosphorus concentration was influenced by $P$ supply and AMF inoculation. The effect of mycorrhizal inoculation on soil phosphorus concentration was higher in soil with $P$ input than in soil without $P$ input. However, in sterilized soil, mycorrhizal inoculation had a depressant effect on soil phosphorus concentration, especially without phosphorus input. The results suggest that the introduced Rhizophagus iregularis strain increase phosphorus uptake in the rhizospheric soil, especially when phosphorus is not applied to the sterilized or unsterilized soil. Our findings are in line with those of Rakshit and Bhadoria (2010) who have observed that soil with mycorrhizal plant contained significantly lower amounts of $P$ than those with nonmycorrhizal plants indicating that plants in AMF symbiosis absorbed more $\mathrm{P}$ from the soil than the nonmycorrhizal plants. The high level of functional diversity in the symbioses between the plant and different CMAs according to benefits and cost could explain the success or failure of an endomycorrhizal symbiosis (Smith et al., 2008; Ortas, Zeina and Sari, 2010). Other studies therefore suggest that the response to mycorrhizal inoculation depends not only on the plant species but also on the MFA strain (Sensoy et al., 2007; Ndoye et al., 2016).

acidic soils, $P$ supply could significantly influence the effect of mycorrhizal inoculation on root development and root abundance. AMF inoculation significantly increased the shoot $P$ concentration when $P$ is supplied. This effect was higher in unsterilized soil than in sterilized soil condition. The results showed that the introduced Rhizophagus iregularis strain increased phosphorus uptake, especially when phosphorus is not supplied regardless of soil conditions. 
Ndeko et al., J. Appl. Biosci. 2020 Comparative effect of Rhizophagus irregularis strain on cassava root development and Phosphorus uptake under acidic soils conditions of Walungu territory, Eastern DR Congo

\section{ACKNOWLEDGEMENTS}

Authors acknowledge the Université Evangélique en Afrique for manifold support to this work which was graciously been funded through the University project on

\section{REFERENCES}

Agbaje, G. O., \& Akinlosotu, T. A. (2004). Influence of NPK fertilizer on tuber yield of early and lateplanted cassava in a forest alfisol of southwestern Nigeria, 3(October), 547-551.

Aime, D., Begoude, B., Sarr, P. S., Laure, T., Mpon, Y., Alexis, D., Araki, S. (2016). Composition of arbuscular mycorrhizal fungi associated with cassava (Manihot esculenta Crantz) cultivars as influenced by chemical fertilization and tillage in Cameroon, 9270-9283.

Azcón-Aguilar, \& José, J. M. B. (1997). Arbuscular mycorrhizas and biological control of soil-borne plant pathogens - an overview of the mechanisms involved - Semantic Scholar. Mycorrhiza. Doi: 10.1007/s005720050147

Bagula, Pypers, Mushagalusa, and M. (2014). Assessment of Fertilizer Use Efficiency of Maize in the Weathered Soils of Walungu District, DR Congo, (October 2016). doi: 10.1007/978-3-319-07662-1

Biró, B., Köves-péchy, K., Vörös, I., Takács, T., Eggenberger, P., \& Strasser, R. J. (2000). Interrelations between Azospirillum and Rhizobium nitrogen-fixers and arbuscular mycorrhizal fungi in the rhizosphere of alfalfa in sterile, AMF-free or normal soil conditions, 15 , 159-168.

Carretero, C. L., Cantos, M., Garc, L., \& Troncoso, A. (2009). Growth Responses of Micropropagated Cassava Clones as Affected by Glomus Intraradices, 261-273. doi: 10.1080/019041 60802608601

Cassman, K. G., Dobermann, A. R., \& Walters, D. T. (2002). Digital Commons @ University of Nebraska - Lincoln Agroecosystems, Nitrogenuse Efficiency, and Nitrogen Management, 2030(November 2017). doi:10.1579/00447447-31.2.132

Cavender, N. D., Atiyeh, R. M., \& Knee, M. (2003). Vermicompost stimulates mycorrhizal colonization of roots of Sorghum bicolor at the expense of plant growth, 85-89.

Cox, T. P. (2008). The land as a casualty: Soil, cattle, and the future in south kivu, DRC, (October). http://www.cialca.org/files/files/Student\% improvement of research and teaching quality funded by Pain pour le Monde (Projet A-COD-2018-0383).

20Thesis/PaulCox-SouthKivu.pdf.

Dalpé, Y. (2005). Les mycorhizes : un outil de protection des plantes mais non une panacée. Phytoprotection, 86(1), 53-59.

Dave, S., \& Tarafdar, J. C. (2011). In Chlorophytum borivilianum Effect of vesicular arbuscular mycorrhizae on growth and saponin accumulation in Chlorophytum borivilianum, (June). doi:10.2306/scienceasia15131874.2011.37.165

Gil-Cardeza, M. L., Calonne-Salmon, M., Gómez, E., \& Declerck, S. (2017). Short-term chromium (VI) exposure increases phosphorus uptake by the extraradical mycelium of the arbuscular mycorrhizal fungus Rhizophagus irregularis MUCL 41833. Chemosphere, 187, 27-34. doi:doi:10.1016/j.chemosphere.2017.08.079

Gryndler, M. (2000). Interactions of arbuscular mycorrhizal fungi with other soil organisms. Arbuscular Mycorrhizas: Physiology and Function, 239-262. doi: 10.1007/978-94-0170776-3_11

Guissou, T. (2009). Contribution of arbuscular mycorrhizal fungi to growth and nutrient uptake by jujube and tamarind seedlings in a phosphate (P)-deficient soil. African Journal of Microbiology Research, 3(5), 297-304.

Hinsinger, P., Yacine, N., Ndour, B., Becquer, T., Chapuis-lardy, L., \& Masse, D. (2015). Les enjeux liés au phosphore dans les sols tropicaux, (January).

Jansa, J., Mozafar, A., \& Frossard, E. (2005). Phosphorus Acquisition Strategies within Arbuscular Mycorrhizal Fungal Community of a Single Field Site. Plant and Soil, 276(1-2), 163176. doi: $10.1007 / s 11104-005-4274-0$

Kintché, K., Hauser, S., Mahungu, N. M., Ndonda, A., Lukombo, S., Nhamo, N., Matungulu, K. P. (2017). Cassava yield loss in farmer fields was mainly caused by low soil fertility and suboptimal management practices in two provinces of the Democratic Republic of Congo. European Journal of Agronomy, 89(June), 107123. doi:10.1016/j.eja.2017.06.011

Mohammad, J., Malkawi, I., \& Shibli, R. (2003). Effects 
of Arbuscular Mycorrhizal Fungi and Phosphorus Fertilization on growth and nutrient uptake of Barley Grown on soils with different levels of salts. Journal of Plant Nutrition, 26(1), 125-137. doi: 10.1081/PLN-120016500

Munyahali, W., Pypers, P., Swennen, R., Walangululu, J., \& Vanlauwe, B. (2017). Field Crops Research Responses of cassava growth and yield to leaf harvesting frequency and NPK fertilizer in South Kivu, Democratic Republic of Congo. Field Crops Research, 214(September), 194-201. doi:10.1016/j.fcr.2017.09.018

Ndoye, F., Diedhiou, A. G., Gueye, M., \& Fall, D. (2016). Réponse du fonio blanc ( Digitaria exilis Stapf ) à I' inoculation avec des champignons mycorhiziens à arbuscules en conditions semicontrôlées, 9784-9799.

Ndoye, F., Kane, A., Bakhoum, N., Sanon, A., Fall, D., Diouf, D., Noba, K. (2013). Response of Acacia Senegal (L.) Willd. to inoculation with arbuscular mycorrhizal fungi isolates in sterilized and unsterilized soils in Senegal. Agroforestry Systems, 87(4), 941-952. doi:10.1007/s10457-013-9610-4

Neumann, E., \& George, E. (2004). Colonisation with the arbuscular mycorrhizal fungus Glomus mosseae (Nicol. \& Gerd.) enhanced phosphorus uptake from dry soil in Sorghum bicolor (L.). Plant and Soil, 261(1-2), 245-255.

Okon, I. E. (2010). The Effects of Arbuscular Mycorrhizal Fungal Inoculation and Mulch of Contrasting Chemical Composition on the Yield of Cassava under Humid Tropical Conditions, (May 2014). doi:10.1100/tsw.2010.59

Ortas, I., Zeina, N., \& Sari, M. (2010). Screening mycorrhiza species for plant growth, $\mathrm{P}$ and $\mathrm{Zn}$ uptake in pepper seedling grown under greenhouse conditions. Sci. Hortic., (November 2017). doi:10.1016/j.scienta.2010.12.014

Pellet, D., \& E-sharkawy, M. A. (1993). Cassava varietal response to phosphorus fertilization. I. Yield, biomass and gas exchange 1, 35 .

Pypers, P., Sanginga, J. M., Kasereka, B., Walangululu, M., \& Vanlauwe, B. (2011). Increased productivity through integrated soil fertility management in cassava-legume intercropping systems in the highlands of Sud-Kivu, DR Congo. Field Crops Research, 120(1), 76-85. doi:10.1016/j.fcr.2010.09.004

Rakshit, A., \& Bhadoria, P. S. (2010). Role of VAM on growth and phosphorus nutrition of maize with low soluble phosphate fertilization. ACTA AGRONOMICA, 59(1), 119-123.

Sawers, R. J. H., Svane, S. F., Quan, C., Grønlund, M., Wozniak, B., Ch, R. A., Paszkowski, U. (2017). Phosphorus acquisition efficiency in arbuscular mycorrhizal maize is correlated with the abundance of root-external hyphae and the accumulation of transcripts encoding PHT1 phosphate transporters. doi:10.1111/nph.14403

Sensoy, S., Demir, S., Turkmen, O., Erdinc, C., \& Savur, O. B. (2007). Responses of some different pepper (Capsicum annuum L.) genotypes to inoculation with two different arbuscular mycorrhizal fungi. Scientia Horticulturae, 113(1), 92-95. doi:10.1016/j.scienta.2007.01.023

Sieverding, E., \& Howeler, R. H. (1985). Influence of species of VA mycorrhizal fungi on cassava yield response to phosphorus fertilization Cassava, Manihot esculenta Crantz, is a crop extremely well-adapted mycorrhizal fungi take up $P$ from the same sources which are also. Plant and Soil, Internacional, Centro Tropical, De Agricultura, 221, 213-221.

Smith, S. E., Read, D., Smith, S. E., \& Read, D. (2008). 2 - Colonization of roots and anatomy of arbuscular mycorrhizas. Mycorrhizal Symbiosis, 42-90. doi:10.1016/B978012370526-6.50004-0

Sow, H. ., Diop, T. ., Ndiaye, F., Manga, A. G. ., \& Diallo, A. (2016). Influence de la mycorhization arbusculaire sur la culture intensive de l'oignon (Allium cepa I.) au Senegal. Researchgate, Journal Des Sciences, 8 (1)(March), 1-6.

Taylor, P., Aryal, U. K., Xu, H. L., \& Fujita, M. (2014). Rhizobia and AM Fungal Inoculation Improve Growth and Nutrient Uptake of Bean Plants Under Organic Fertilization Rhizobia and AM Fungal Inoculation Improve Growth and Nutrient Uptake of Bean Plants Under Organic Fertilization, (October2014), 37-41. doi:10.1300/J064v21n03

Turrini, A., Bedini, A., Loor, M. B., Santini, G., Sbrana, C., Giovannetti, M., \& Avio, L. (2017). Local diversity of native arbuscular mycorrhizal symbionts differentially affects growth and nutrition of three crop plant species. 